\title{
KELIMPAHAN IKAN KARANG PADA KAWASAN TERUMBU BUATAN DI PERAIRAN RATATOTOK SULAWESI UTARA
}

\section{THE ABUNDANCE OF CORAL FISH IN ARTIFICIAL REEFS AREA OF RATATOTOK WATERS, NORTH SULAWESI}

\author{
Indri Manembu, L.Adrianto, D. Bengen dan F.Yulianda \\ Mahasiswa pada Fakultas Perikanan Ilmu Kelautan IPB Bogor \\ Teregistrasi I tanggal: 20 Mei 2013; Diterima setelah perbaikan tanggal: 08 April 2014; \\ Disetujui terbit tanggal: 10 April 2014 \\ Email: indrimanembu@gmail.com
}

\begin{abstract}
ABSTRAK
Ekosistem terumbu karang merupakan salah satu potensi sumberdaya laut yang sangat penting bagi kehidupan manusia. Potensi sumberdaya ikan karang di perairan Indonesia perlu diketahui agar dapat dikembangkan sebagai salah satu aset dalam kegiatan pariwisata bahari. Penelitian yang dilakukan tahun 2009-2011 bertujuan untuk mengetahui kelimpahan dan komposisi jenis ikan karang pada kawasan terumbu buatan di perairan Ratatotok. Metode line transect dan sensus visual pada perairan seluas $250 \mathrm{M}^{2}$ digunakan untuk mengetahui kelimpahan ikan karang dengan keragaman jenis pada masing-masing stasiun pengamatan pada kedalaman 10 meter. Hasil penelitian telah teridentifikasi sebanyak 116 spesies ikan pada terumbu buatan Stasiun 1 (daerah Teluk Buyat); 112 spesies pada terumbu buatan Stasiun 2 (daerah Tanjung) dan pada terumbu alami di Stasiun 3 (daerah Ratatotok) sebanyak 88 spesies. Kelimpahan ikan pada kawasan terumbu buatan lebih tinggi pada kisaran 24-28 spesies daripada karang alami. Kelimpahan spesies ikan dari famili Pomacentridae mendominasi ketiga stasiun pengamatan dengan 19 spesies dan yang paling sedikit dari famili Anomalopidae yang hanya ditemukan 1 spesies.
\end{abstract}

KATA KUNCI: Kelimpahan, ikan karang, Ratatotok, Sulawesi Utara.

ABSTRACT

Coral reef ecosystem is one of important natural resources in tropical waters. It has some coral reeffishes, species of corals and others biota that have several most interesting ecotourism extraction scientific and educational objects. The aim of this study is to determine the abundance of coral fish composition surrounded in artificial reefs area in Ratatotok waters. This study was done during 2009 to 2011 by using the visual census and line transect methods within area of $250 \mathrm{M}^{2}$ to observe the species composition and diversitas of coral fishes founded in three sites at the depth of $10 \mathrm{~m}$ from sea surface. The results showed that there were 116 species in Site 1(Buyat bay); 112 species in Site 2 (Tanjung) and 88 species of coral reeffishes in Site 3 (Ratatotok). Fishes of Pomacentridae were found 19 species in all locations. Only one species fish of Anomalopidae was found.

KEYWORDS: Abundance, coral fish, Ratatotok, North Sulawesi.

\section{PENDAHULUAN}

Ekosistem terumbu karang merupakan ekosistem khas pesisir dan laut tropis yang memiliki produktivitas tinggi dan menyediakan makanan berlimpah bagi berbagai jenis ikan karang, kerang, kepiting dan biota asosiasi lainnya. Selain itu ekosistem ini merupakan tempat berkembang biak, memijah dan pembesaran bagi berbagai jenis hewan laut (Bengen, 2004).

Penelitian di perairan Ratatotok menunjukkan sebagian besar terumbu karang berada pada kondisi cukup dengan tutupan karang hidup antara 25\%-49\% (Lalamentik, 2005). Percepatan kerusakan terumbu karang lebih banyak karena aktivitas manusia yang tidak terkontrol di daerah tersebut. Limbah industri dan limbah rumah tangga serta pencemaran minyak juga mengancam kelestarian terumbu karang (Wilkinson, 2008)

Korespondensi penulis.

Fakultas Perikanan Ilmu Kelautan. Institut Pertanian Bogor

Jl. Raya Darmaga Bogor-Jawa Barat, 16003.
Salah satu kelompok biota laut yang hidup di daerah terumbu karang dan memiliki nilai ekonomi tinggi adalah ikan karang. Ikan karang selain sebagai ikan konsumsi juga memiliki nilai sebagai ikan hias (ornamental fishes). Menurut Dartnall \& Jones (1986), ikan karang dapat dikelompokan menjadi tiga kelompok berdasarkan tujuan pengelolaan, yaitu kelompok ikan target (ikan ekonomis/ konsumsi), kelompok ikan indikator dan kelompok ikan mayor (berperan dalam rantai makanan).

Komunitas ikan karang memiliki keaneragaman spesies sebanding dengan keanekaragaman spesies karang batu. Tingginya keragaman ini disebabkan oleh variasi habitat yang ada di terumbu karang, dimana semua tipe habitat tersebut diisi oleh spesies ikan karang (Emor, 1993). Sekitar $50-70 \%$ ikan yang ada di terumbu karang merupakan kelompok ikan karnivor, 15-20\% kelompok herbivor dan sisanya omnivor. Ikan dari kelompokkelompok tersebut sangat bergantung kepada kesehatan 
karang untuk mengembangkan populasinya. Sebagian besar ikan karang memiliki diversitas yang tinggi, jumlah spesies yang banyak dan rentang morfologi yang luas (Nybakken, 1988).

Kerusakan terumbu karang yang tersebar di perairan Ratatotok lebih banyak disebabkan oleh praktek penangkapan ikan yang tidak ramah lingkungan. Dalam beberapa kasus menunjukan bahwa terumbu buatan dapat meningkatkan kelimpahan ikan karena ketersediaan shelter (tempat berlindung), dimana sumber bahan makanan yang ada di terumbu kurang penting bagi ikan yang menempatinya (Miller \&Falace 2000).

Penempatan terumbu buatan di pesisir Ratatotok dan sekitarnya telah dilakukan pada tahun 1999 dengan tujuan awal untuk membangun habitat yang dapat ditempati kembali oleh berbagai biota yang berasosiasi dengan karang sehingga dapat meningkatkan populasi ikan ekonomis penting. Program ini dilaksanakan karena masyarakat di sekitar perairan tersebut menganggap bahwa telah terjadi penurunan populasi ikan akibat semakin banyak lokasi terumbu karang yang telah rusak akibat praktek penangkapan ikan yang tidak ramah lingkungan, seperti penggunaan bom dan sianida yang telah terjadi selama ini (Kojansow, 2002).

Peletakkan terumbu buatan di pesisir Ratatotok dan sekitarnya diharapkan berkontribusi penting dalam upaya pemulihan fungsi ekologis dari ekosistem terumbu karang yang ada di sekitarnya.

Penelitian ini bertujuan untuk mengetahui keanekaragaman jenis ikan karang di kawasan terumbu buatan perairan Ratatotok Sulawesi Utara yang dapat menjadi acuan untuk pemanfaatan kawasan terumbu buatan ke depan dalam pengembangan sebagai lokasi wisata bahari dan perikanan tangkap skala kecil.

\section{BAHANDANMETODE}

Penelitian dilakukan melalui tiga stasiun pengamatan pada kawasan terumbu buatan di perairan Ratatotok, Sulawesi Utara, stasiun 1 (daerah Teluk Buyat) dan stasiun 2 (daerah Tanjung) terdapat di daerah terumbu buatan dan stasiun 3 (daerah Teluk Totok) terdapat di terumbu karang alami (Gambar 1). Waktu pengamatan dilakukan selama 3 tahun berturutan, yaitu tahun 20092011.

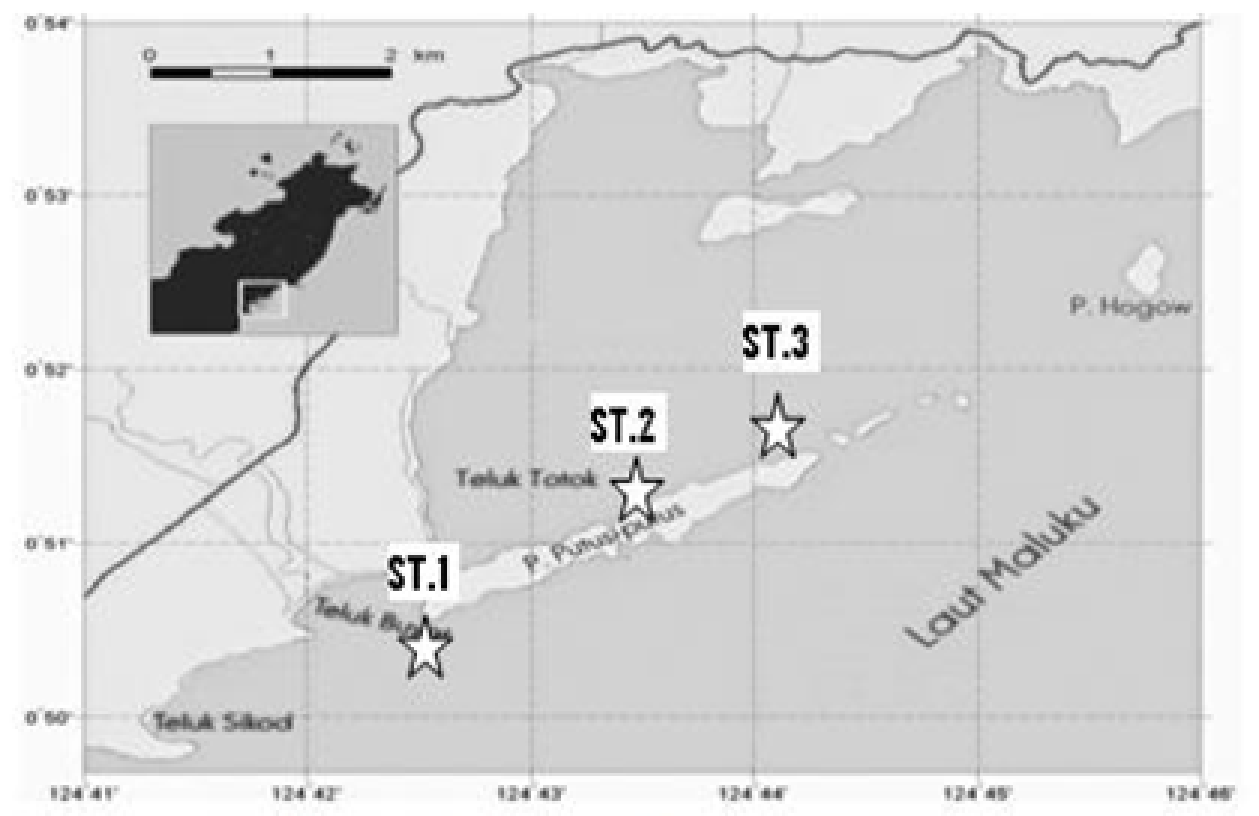

Gambar 1. Peta stasiun penelitian di perairan Ratatotok Sulawesi Utara

Figure 1. Map showing sampling sites in Ratatotok waters, North Sulawesi

Pencatatan data menggunakan metoda transek garis lurus dan sensus visual (Dartnall \& Jones, 1986) yang telah dimodifikasi sesuai dengan kebutuhan dan kemampuan serta sarana yang tersedia. Transek sepanjang 50 meter diletakan permanen pada kedalaman 10 meter. Sensus visual dilakukan dengan menyelusuri sepanjang garis transek dengan jarak pengamatan sejauh lima meter ke kiri dan kanan garis transek, sehingga luas area transek yang diamati pada adalah $50 \mathrm{~m}$ x $5 \mathrm{~m}$. Identifikasi ikan mengacu pada English et al. (1994). Untuk penyederhanaan proses analisis data kuantitatif, ikan dibedakan menjadi tiga kelompok besar, yakni kelompok 
ikan indikator (indicator species), kelompok ikan target (target species) dan kelompok ikan lain (major group species) sebagaimana yang digunakan oleh Hutomo (1986).

Kelimpahan ikan karang didefinisikan sebagai jumlah ikan karang yang ditemukan pada suatu stasiun pengamatan persatuan luas transek pengamatan. Kelimpahan ikan karang dapat dihitung dengan persamaan Odum (1971) sebagai berikut:

Keterangan:

$$
X=\frac{X i}{n}
$$

$\mathrm{X}=$ Kelimpahan ikan karang

$X i=$ Jumlah ikan pada stasiun pengamatan ke-i

$\mathrm{n} \quad=$ Luas transek pengamatan

\section{HASIL DAN BAHASAN}

\section{HASIL}

\section{Komposisi dan Distribusi Ikan Karang}

Secara keseluruhan, di ketiga stasiun selama tiga tahun pengamatan diperoleh 24 famili yang terdiri atas 162 spesies dan 13.375 individu ikan di terumbu karang. Masing-masing lokasi memiliki komposisi jenis ikan yang berbeda, baik jumlah spesies maupun jumlah individunya.

Jumlah spesies paling banyak diketemukan di stasiun 1 (tahun 2009) dan jumlah individu terbanyak di stasiun 1 (tahun 2011). Jumlah spesies dan individu paling sedikit ditemukan di stasiun 3 pada tahun 2011 (Tabel 1).

Distribusi 12 famili ikan target ditemukan pada stasiun 1 dan 2; pada stasiun 3 hanya ditemukan 10 famili. Jumlah ikan mayor di stasiun 1, secara keseluruhan pada tahun 2009 ditemukan 11 famili, tahun 2010 ditemukan 9 famili, dan pada tahun 2011 ditemukan 10 famili. Ikan indikator yaitu famili Chaetodontidae ditemukan di semua stasiun selama 3 tahun pengamatan (Tabel 2).

Kelimpahan ikan target selama tiga tahun, baik jumlah spesies maupun individu tidak terlihat trend naik atau turun. Jumlah spesies terbanyak terdapat di stasiun 1 pada tahun 2009 dan 2010 yaitu 56 spesies, di stasiun 3 pada tahun 2011 paling sedikit hanya berjumlah 38 spesies. Jumlah individu ikan target terbanyak di stasiun 1 pada tahun 2009 yaitu 965 individu, sedangkan paling sedikit di stasiun 3 pada tahun 2011 yang hanya berjumlah 218 individu (Tabel 1).

Komposisi kelimpahan ikan indikator berbeda-beda, menurut waktu dan lokasi pengamatan. Jumlah spesies ikan indikator menurun selama tiga tahun pada stasiun 1 , sedangkan pada stasiun 2 tetap, dan pada stasiun 3 cenderung menurun. Jumlah individu hanya pada stasiun 2 yang mempunyai trend naik selama 3 tahun. Jumlah spesies ikan indikator terbanyak terdapat di stasiun 1 pada tahun 2009 yaitu 14 spesies, sedangkan paling sedikit di stasiun 3 pada tahun 2009 dan 2011 berjumlah 9 spesies. Jumlah individu ikan indikator terbanyak terdapat di stasiun 1 pada tahun 2009 yaitu 103 individu, dan paling sedikit di stasiun 3 pada tahun 2009 yang hanya berjumlah 59 individu (Tabel 1).

\section{Kelimpahan Ikan \\ Stasiun 1}

Jumlah spesies dari tiga kategori ikan pada terumbu karang di stasiun 1 selama 3 tahun pengamatan cenderung menurun tetapi jumlah individu meningkat. Jumlah ikan pada tahun 2009 sebanyak 120 spesies menjadi 115 spesies pada tahun 2011, dengan jumlah individu meningkat dari 2.432 menjadi 2.474 ikan (Tabel 3).

\section{Stasiun 2}

Jumlah spesies dari tiga kategori ikan pada terumbu karang di stasiun 2 meningkat selama 3 tahun. Jumlah ikan pada tahun 2009 sebanyak 109 spesies menjadi 112 spesies pada tahun 2011, dan jumlah individu dari 1.513 menjadi $1.721 \mathrm{ikan}$ (Tabel 4).

\section{Stasiun 3}

Jumlah spesies dan individu di stasiun 3 mengalami penurunan. Jumlah ikan pada tahun 2009 sebanyak 89 spesies menjadi 85 spesies pada tahun 2011, setelah mengalami peningkatan menjadi 90 spesies pada tahun 2010. Demikian juga dengan jumlah individu, dari 867 ekor pada tahun 2009, menurun menjadi 750 ekor pada tahun 2011 (Tabel 5).

\section{BAHASAN}

Chaetodontidae (Butterfly fishes atau ikan kupu-kupu) merupakan salah satu famili ikan karang yang sering dijumpai di perairan Indo-Pasifik (Kulbicki \& Bozec 2005). Studi mengenai ikan, sudah dibahas dari aspek biologi (Lewis 1998), aspek ekologi (Cadoret et al. 1999) bahkan aspek biogeogafis (Findley \&Findley 2001). Ikan ini juga digunakan untuk memantau status ekologi terumbu karang (Crosby \& Reese, 1996; Samways, 2005).

Dilihat dari komposisi spesies, ikan indikator yang ditemukan di perairan Ratatotok didominasi oleh spesies Chaetodon kleinii yang termasuk famili Chaetodonthidae. Keadaan ini menunjukkan bahwa spesies tersebut memiliki relung ekologi yang luas dan tidak terpengaruh dengan perubahan-perubahan komposisi habitat (kondisi terumbu karang). Penurunan jumlah spesies pada lokasi penelitian 
Tabel 1. Komposisi ikan karang di perairan Ratatotok pada transek seluas $\left(250 \mathrm{~m}^{2}\right)$

Table 1. Composition of reef fish in Ratatotok waters in transect of $\left(250 \mathrm{~m}^{2}\right)$

\begin{tabular}{lrrrrrrrrrr}
\hline & \multicolumn{3}{c}{ Stasiun 1 } & \multicolumn{3}{c}{ Stasiun 2 } & \multicolumn{3}{c}{ Stasiun 3 } \\
\multicolumn{1}{c}{ Parameter } & $\mathbf{2 0 0 9}$ & $\mathbf{2 0 1 0}$ & $\mathbf{2 0 1 1}$ & $\mathbf{2 0 0 9}$ & $\mathbf{2 0 1 0}$ & $\mathbf{2 0 1 1}$ & $\mathbf{2 0 0 9}$ & $\mathbf{2 0 1 0}$ & $\mathbf{2 0 1 1}$ \\
\hline Jumlah spesies & 120 & 112 & 115 & 109 & 116 & 112 & 89 & 90 & 85 \\
Jumlah individu & 2.432 & 2.127 & 2.474 & 1.513 & 1.755 & 1.721 & 867 & 836 & 750 \\
\hline
\end{tabular}

Tabel 2. Distribusi ikan karang di lokasi penelitian selama tiga tahun

Table 2. Distribution of reef fishes in sampling site for three years

\begin{tabular}{|c|c|c|c|c|c|c|c|c|c|c|}
\hline \multirow{2}{*}{ No. } & \multirow{2}{*}{ Famili } & \multicolumn{3}{|c|}{ Stasiun 1} & \multicolumn{3}{|c|}{ Stasiun 2} & \multicolumn{3}{|c|}{ Stasiun 3} \\
\hline & & 2009 & 2010 & 2011 & 2009 & 2010 & 2011 & 2009 & 2010 & 2011 \\
\hline \multirow{3}{*}{1.} & Ikan Indikator & & & & & & & & & \\
\hline & Chaetodontidae & + & + & + & + & + & + & + & + & + \\
\hline & Ikan Target & & & & & & & & & \\
\hline 2. & Acanthuridae & + & + & + & + & + & + & + & + & + \\
\hline 3. & Caesionidae & + & + & + & + & + & + & - & - & - \\
\hline 4. & Haemulidae & + & + & + & + & + & + & + & + & + \\
\hline 5. & Holocentridae & + & + & + & + & + & + & - & - & - \\
\hline 6. & Labridae & + & + & + & + & + & + & + & + & + \\
\hline 7. & Lethrinidae & + & + & + & + & + & + & + & + & + \\
\hline 8. & Lutjanidae & + & + & + & + & + & + & + & + & + \\
\hline 9. & Mullidae & + & + & + & + & + & + & + & + & + \\
\hline 10. & Nemipteridae & + & + & + & + & + & + & + & + & + \\
\hline 11. & Scaridae & + & + & + & + & + & + & + & + & + \\
\hline 12. & Serranidae & + & + & + & + & + & + & + & + & + \\
\hline 13. & Siganidae & + & + & + & + & + & + & + & + & + \\
\hline
\end{tabular}

\section{Ikan Mayor}

14. Anomalopidae

15. Anthiinae

16. Apogonidae

17. Balistidae

18. Ephippidae

19. Labridae

20. Murainidae

21. Ostraciidae

22. Pomacentridae

23. Scorpaenidae

24. Tetraodontidae

Keterangan/Remarks : (+) ditemukan/found in

$\begin{array}{lllllllll}+ & + & + & - & - & - & + & + & + \\ + & + & + & + & + & + & + & + & + \\ + & + & - & + & + & + & + & + & + \\ + & + & + & + & + & + & + & + & + \\ + & + & + & + & + & + & - & - & - \\ + & + & + & + & + & + & + & + & + \\ + & + & + & - & - & - & + & + & + \\ - & - & + & + & + & + & + & + & + \\ + & + & + & + & + & + & + & + & + \\ + & + & + & + & + & + & + & + & - \\ + & + & + & + & + & + & + & + & +\end{array}$

(-) tidak ditemukan/not found 
Tabel 3. Jumlah spesies dan individu ikan karang di Stasiun 1.

Table 3. Number of reef fishes by species and individuals at Station 1.

\begin{tabular}{|c|c|c|c|c|}
\hline \multirow{2}{*}{\multicolumn{2}{|c|}{ Kategori Ikan }} & \multicolumn{3}{|c|}{ Tahun } \\
\hline & & 2009 & 2010 & 2011 \\
\hline \multirow[t]{2}{*}{ Indikator } & Spesies & 14 & 13 & 12 \\
\hline & Individu & 103 & 77 & 91 \\
\hline \multirow[t]{2}{*}{ Target } & Spesies & 56 & 56 & 53 \\
\hline & Individu & 954 & 873 & 896 \\
\hline \multirow[t]{2}{*}{ Mayor } & Spesies & 50 & 43 & 50 \\
\hline & Individu & 1.375 & 1.177 & 1.487 \\
\hline \multicolumn{2}{|c|}{ Jumlah Spesies } & 120 & 112 & 115 \\
\hline \multicolumn{2}{|c|}{ Jumlah Individu } & 2.432 & 2.127 & 2.474 \\
\hline
\end{tabular}

Tabel4. Jumlah spesies dan individu ikan karang di Stasiun 2.

Table 4. Number of reef fishes by species and individuals at Station 2.

\begin{tabular}{|c|c|c|c|c|}
\hline \multirow{2}{*}{\multicolumn{2}{|c|}{ Kategori Ikan }} & \multicolumn{3}{|c|}{ Tahun } \\
\hline & & 2009 & 2010 & 2011 \\
\hline \multirow[t]{2}{*}{ Indikator } & Spesies & 13 & 13 & 13 \\
\hline & Individu & 72 & 78 & 79 \\
\hline \multirow[t]{2}{*}{ Target } & Spesies & 47 & 52 & 50 \\
\hline & Individu & 389 & 548 & 436 \\
\hline \multirow[t]{2}{*}{ Mayor } & Spesies & 49 & 51 & 49 \\
\hline & Individu & 1.052 & 1.129 & 1.206 \\
\hline \multicolumn{2}{|c|}{ Jumlah Spesies } & 109 & 116 & 112 \\
\hline \multicolumn{2}{|c|}{ Jumlah Individu } & 1.513 & 1.755 & 1.721 \\
\hline
\end{tabular}

tidak memperlihatkan angka yang signifikan. Penurunan jumlah spesies diduga disebabkan ruaya ikan yang terjadi pada musim-musim tertentu sehingga pada waktu pengamatan beberapa jenis tidak ditemukan.

Kelompok ikan target (target species) meliputi ikan konsumsi dan ekonomis penting yang berasosiasi dengan karang, termasuk di antaranya adalah kakap (Lutjanus sp.) dari famili Lutjanidae, kerapu (Epinephelus sp.) dari famili Serranidae, baronang (Siganus sp) dari famili Siganidae, serta beberapa jenis yang selalu diburu nelayan dengan menggunakan berbagai jenis alat tangkap. Ada beberapa jenis ikan target yang dijumpai dalam kelompok besar misalnya ikan ekor kuning (Caesio sp.) dari famili Caesionidae.

Jenis-jenis ikan yang dikelompokan sebagai major group meliputi semua ikan yang tidak termasuk dalam
Tabel 5. Jumlah spesies dan individu ikan karang di Stasiun 3.

Table 5. Number of reef fishes by species and individuals at Station 3.

\begin{tabular}{llrcc}
\hline \multicolumn{2}{l}{ Kategori Ikan } & \multicolumn{3}{c}{ Tahun } \\
\hline \multirow{2}{*}{ Indikator } & Spesies & 9 & 10 & 9 \\
& Individu & 59 & 66 & 61 \\
\hline Target & Spesies & 41 & 42 & 38 \\
& Individu & 339 & 282 & 218 \\
\hline Mayor & Spesies & 39 & 38 & 38 \\
& Individu & 469 & 488 & 471 \\
\hline Jumlah Spesies & 89 & 90 & 85 \\
\hline Jumlah Individu & 867 & 836 & 750 \\
\hline
\end{tabular}

kedua kelompok di atas. Umumnya hidup dalam kelompok besar (schooling fish), misalnya ikan Betok Chromis ternatensis, C. margaritifer dan Dascillus reticulatus dari famili Pomacentridae, beberapa jenis ikan dari famili Pomacanthidae, Serranidae, Acanthuridae dan Labridae.

Hasil pengamatan menunjukan bahwa beberapa spesies ikan memiliki preferensi habitat yang luas dan kelimpahan yang tinggi, seperti Zanclus cornutus dan Zebrasoma scopas. Famili Haemulidae hanya ditemukan beberapa individu pada stasiun pengamatan. Kondisi yang diperoleh pada ikan karang (baik spesies indikator maupun spesies target) mengikuti kondisi yang diperoleh pada karang batu. Kondisi terumbu karang secara umum (persentase tutupan, keanekaragaman, maupun jumlah koloni karang batu) di stasiun 1 menunjukkan kondisi perairan yang baik yang antara lain disebabkan oleh posisinya yang jauh dari aliran sungai sehingga perairannya lebih jernih dan bersih.

Kenaikan jumlah individu tentu saja merupakan indikator yang baik bagi ekosistem terumbu karang di lokasi pengamatan. Ikan indikator dapat menjadi tolok ukur dalam peningkatan kualitas perairan, karena peningkatan ikan indikator mempunyai korelasi posistif dengan kualitas lingkungan relung pada suatu ekosistem.

Peningkatan dan penurunan jumlah spesies dan individu pada stasiun 2 diduga karena intensitas pemanfaatan yang tinggi oleh nelayan setempat mengingat harga dari ikan-ikan ini memiliki nilai ekonomis.

Penurunan jumlah individu pada stasiun 3 diduga diakibatkan oleh menurunnya kualitas terumbu karang pada kawasan ini yang tidak seperti pada stasiun lainnya yang didukung oleh terumbu karang buatan yang berfungsi sebagai spawning ground, nursery ground, dan 
feeding ground bagi ikan karang yang berada di sekitarnya. Selain itu penangkapan ikan target yang berlebihan terindikasi pada stasiun 3 ini. Hal ini terlihat dari bekas jaring dan alat tangkap lain banyak ditemukan di daerah tersebut.

Konstruksi terumbu buatan memiliki kegunaan yang berbeda pada tiap tempat. Contohnya di Amerika Serikat, terumbu buatan diperuntukkan bagi aktivitas rekreasi perikanan, di Jepang untuk meningkatkan keuntungan sektor perikanan dan di beberapa negara Eropa berfungsi untuk mengontrol penggunaan alat tangkap pukat di pesisir pantai dan untuk meningkatkan produksi ikan bagi komunitas nelayannya (Wilkinson, 2008).

Terumbu buatan reef ball yang ada di lokasi penelitian selain telah berperan sebagai substrat karang, juga telah berhasil menjadi habitat bagi ikan karang. Konstruksi reef ball yang sangat sesuai sebagai tempat berlindung dan mencari makan menjadikan banyak ikan yang hidup di tempat ini.

Jumlah individu total pada masing-masing stasiun di lokasi penelitian dapat menggambarkan kualitas lingkungan perairan tersebut. Peningkatan jumlah spesies seringkali diikuti oleh peningkatan jumlah individu. Stasiun 1 memiliki jumlah individu dan jumlah spesies tertinggi, sedangkan yang terendah pada Stasiun 3. Apabila dihubungkan dengan persen penutupan terumbu karang maka dapat disimpulkan bahwa peningkatan persen penutupan akan diikuti oleh peningkatan jumlah spesies dan individu ikan karang, korelasi positif yang terjadi antara terumbu karang dan ikan karang dapat diasumsikan juga apabila perbaikan lingkungan ditingkatkan maka akan meningkatkan produktivitas dari suatu perairan. Kontribusi terumbu buatan sangat menunjang peningkatan kualitas ekosistem terumbu karang dan berimplikasi langsung terhadap biodivesitas ikan karang.

Selama penelitian berlangsung perolehan hasil sensus visual menunjukkan bahwa hasil sensus tersebut relatif lebih tinggi jika dibandingkan dengan hasil yang diperoleh Kumar et al. (2008) yang menemukan beragam jenis ikan karang yang mewakili 20 famili di perairan India, dan famili Pomacentridae menduduki urutan teratas $(35,34 \%)$, diikuti famili Labridae (14,44\%) dan Chaetodontidae (11,50\%). Becira et al. (2010) yang menemukan jenis-jenis ikan karang di perairan gugusan Pulau-pulau Kalayaan, Filipina sebanyak 40 famili, yang didominasi oleh famili Acanthuridae (36,75\%), diikuti oleh famili Pomacentridae (18,21\%), Labridae (14,57\%) dan Serranidae (12,58\%). Keadaan ini diduga berhubungan erat dengan kondisi kenaekaragaman terumbu karang dilokasi penelitian yang relatif lebih baik daripada lokasi-lokasi lainnya.

\section{KESIMPULAN}

Ekosistem terumbu karang di Perairan Ratatotok Sulawesi Utara memiliki kelimpahan ikan karang yang cukup tinggi. Komposisi jenis ikan yang ditemukan di perairan karan Ratatotok terdiri dari 24 famili dengan 162 spesies dan 13.375 individu. Kelimpahan spesies ikan dari famili Pomacentridae mendominasi ketiga stasiun pengamatan dengan 19 spesies dan paling sedikit dari famili Anomalopidae yang hanya ditemukan 1 spesies. Distribusi jenis ikan karang di daerah terumbu buatan lebih tinggi dibandingkan dengan daerah karang alami (daerah Ratatotok). Hal ini mengindikasikan bahwa terumbu buatan telah berkembang menjadi habitat yang disukai oleh ikan karang. Dengan demikian diharapkan terumbu buatan di Ratatotok Sulawesi Utara dapat dimanfaatkan sebagai lokasi wisata bahari ataupun fishing ground ikan karang.

\section{DAFTAR PUSTAKA}

Becira, J.G., B.J. Gonzales \& N. D. Dieron. 2010. Reef fishes in Pagasa Island, Kalayaan Islands Group, Palawan, Philippines. 56 pp.

Bengen, D.G. 2004. Ekosistem dan sumberdaya alam pesisir. Sinopsis. PKSPL, Institut Pertanian Bogor. 72 hal.

Cadoret, L., Adjeroud, M. \& M. Tsuchiya. 1999. Spatial distribution of Chaetodontidae fish on coral reefs of the Ryukyu Islands, Southern Japan. Journal of the Marine Biological Association of UK 79. 725-735.

Choat, J.H. \& D. R. Bellwood. 1991. The ecology of fishes on coral reefs. Reef fishes: their history and evolution. Sale PF. Eds. Department of Zoology University of New Hamshire Durham. 39-47.

Crosby, M.P. \& E.S. Reese. 1996. A manual for monitoring coral reefs with indicator species: butterflyfishes as indicators of change on Indo-Pacific reefs. Office of Ocean and Coastal Resource Management, National Oceanic and Atmospheric Administration. Silver Spring, MD. 45 pp.

Dartnall, A.J. \& M. Jones. 1986. A manual of survey methods living resources in coastal area. ASEANAuastralia Cooperative Program on Marine Science Hand book. Townsville: Australian Institute of Marine Science. $167 \mathrm{pp}$.

Emor, D. 1993. Hubungan koresponden antara pola sebaran komunitas karang dan komunitas ikan di terumbu karang Pulau Bunaken. Tesis. Program Pascasarjana Institut Pertanian Bogor. 95 hlm. 
English, S., C. Wilkinson \& V. Baker 1994. Survey manual for tropical marine resources. Australian Institute of Marine Science. Townsville. 368 pp.

Findley, J.S. \& M.T. Findley. 2001. Global, regional, and local patterns in species richness and abundance of butterflyfishes. Ecological Monographs.71(1). 69-91.

Hutomo, M. 1986. Komunitas Ikan karang dan metode sensual visual. Diklat Latihan Metodologi Penelitian Komunitas Mangrove, Koral dan Substrat Lunak. P2O-LIPI. 21 hal.

Kojansow, J. 2002. Terumbu buatan "reef ball": Manfaat dan Fungsi Ekologisnya. Departemen Lingkungan PT. Newmont Minahasa Raya. Indonesia. 176 hal.

Kumar, A.T.T., K.V. Dhaneesh, M. Arumugam \& T. Balasubramanian. 2008. Stability of marine ornamental fishes in captivity: Case Study in Marine Research Aquarium of Annamalai University. Global Journal of Molecular Sciences. 3 (1). 35-41.

Kuiter, R.H. 1992. Tropical reef-fishes of the western Pasific. Indonesia and adjacent water. Gramedia Jakarta. 314 hal.

Kulbicki, M. \& Y.M. Bozec. 2005. Implications of biogeography in the use of butterfly fishes (Chaetodontidae) as indicators for Western and Central Pacific areas. Aquatic Conservation: Marine and Freshwater Ecosystems. 15 (S1). S109-S126.
Lalamentik, L.T.X. 2005. Status of coral reefs in Totok and Buyat bays. Proceeding International Seminar on "Mining Environment, and Sustainable Development: A lesson from the gold mining controversy in Buyat Bay. North Sulawesi, Indonesia”. Sam Ratulangi University Press.

Lantang, R. 2005. Struktur komunitas karang batu pada terumbu buatan "reef ball" di Semenanjung Totok, Minahasa Selatan. Skripsi. Fakultas Perikanan dan Ilmu Kelautan Universitas Sam Ratulangi. Manado.146 hal.

Lewis, A. R. 1998. Effects of experimental coral disturbance on the population dynamics of fishes on large patch reefs. Journal of Experimental Marine Biology and Ecology. 230.91-110.

Nybakken, J.W., 1988. Biologi laut, suatu pendekatan ekologis. Penerbit Gramedia, Jakarta.459 hal.

Samways, M.J. 2005. Breakdown of butter flyfish (Chaetodontidae) territories associated with the onset of a mass coral bleaching event.Aquatic Conservation: Marine and Freshwater Ecosystems. 15 (S1). S101S107.

Wilkinson, C. 2008. Status of coral reefs of the world: 2008. Global Coral Reef Monitoring Network \& Reef Research Centre. Townsville, Australia. 304 pp. 